\title{
Europa og Babylon
}

- tale ved åbningen af udstillingen den 15. marts 1990 på Det kongelige Bibliotek

Af lic.phil. Marie-Louise Thomsen

Denne udstilling er resultatet af flere års forskning og samlen af bøger, billeder og genstande, der illustrerer, hvordan man i Europa igennem tiderne har forestillet sig oldtidsrigerne Assyrien og Babylonien, deres historie, konger, befolkning, religion og levevis. Efterhånden som materialet voksede, opstod $\emptyset$ nsket om at vise det frem, og jeg vil gerne takke Det kongelige Bibliotek, som straks fra første færd var imødekommende overfor min idé om en udstilling, og i hvis samlinger, jeg har gjort mange fund. Specielt vil jeg takke Kontakt- og Oplysningsafdelingens personale: Jesper Düring Jørgensen, Lotte Philipson og Kristian Gandrup for deres engagement og interesse og hjælp i mange praktiske gøremål. Sidst, men ikke mindst takker jeg min mand, Christoph Daxelmüller, for utallige henvisninger og idéer og for hans assistance med opbygningen af udstillingen.

Titlen 'Europa og Babylon' er et noget kortfattet udtryk for det, som udstillingen indeholder, nemlig fremstillinger af både Assyriens og Babyloniens kultur indenfor historieskrivning, videnskabsteorier, litteratur og kunst i Europa siden Antikken og indtil vore dage. Jeg vil gerne understrege, at det ikke er assyriologiens historie, der belyses her, men et stykke europæisk kulturhistorie. Det har desuden været mig magtpåliggende ikke kun at vise traditionen på et elitært, videnskabeligt plan, men lige såvel dens udbredelse i folkekulturen, i populære medier som kisteblade og underholdningslitteratur.

Mange vil måske umiddelbart mene, at det ikke kan være den store betydning, som Babylonien og Assyrien har haft for vores vestlige kultur, men faktisk støder man på denne indflydelse i mange - og ofte uventede - sammenhænge. Udstillingens eksponater er således kun et repræsentativt udvalg af et omfattende materiale. Hyppigst er nok Babelstårnsfremstillinger, der kan findes i utallige varianter næsten hvor som helst, i malerisamlinger, p̊̊ gamle kakler, i billedbøger og tegneserier, som symbol på plakater og na- 
turligvis i bibelillustrationer. Navnet Babylon eller Babel som symbol på kaos og forvirring, mangfoldighed eller moralsk forfald er så almindeligt, at man dårligt nok i den forbindelse tænker på oldtidskulturen.

Før man omkring 1850 begyndte udgravninger i Mesopotamien, hentede man sin viden om det gamle Assyrien og Babylonien fra to traditionsstrømme: Det Gamle Testamente og en række klassiske forfattere. Ifølge dem var de orientalske riger de ældste i verden. I Bibelen begynder historien efter syndfloden med Nimrod, Noahs sønnes $\varnothing n$, den første regent overhovedet. I den klassiske tradition med Ninus og Semiramis, som grundlægger henholdsvis Ninive og Babylon.

I den europæiske historieskrivning synkretiseredes de forskellige overleveringer, og man fik en sammenhængende kronologisk skildring af verdens historie lige siden syndfloden med riger og dynastier, der afløste hinanden, men stadig begyndende med Assyrien. Dette var langt ind $\mathrm{i}$ forrige århundrede den almindelige opfattelse af oldtidshistorien, og det kunne fundene fra Mesopotamien i første omgang ikke rokke ved, tværtimod måtte de passes ind i dette skema.

Assyrien og Babylonien var således i den europæiske tradition historiens ældste skueplads: her lå Paradiset, her havde de første mennesker bosat sig efter syndfloden, og herfra var de enkelte folkeslag draget ud for at befolke jorden, efter at Gud havde forstyrret deres sprog. Dette giver den assyriskbabylonske kultur en særstilling i menneskehedens historie og forklarer den for os i dag måske overraskende store - betydning, som den fik i mange sammenhænge.

Man så i oldtiden en historisk model, men man veg heller ikke tilbage fra at omsætte traditionens oplysninger til ens egen praktiske samtid. Man efterprøvede således i detaljer, hvordan Babelstårnet kunne være konstrueret, udregnede dimensioner, mål, materialer og arbejdskraft. På baggrund især af Herodots detaljerede beskrivelse af Babylon rekonstruerede man byens grundplan, gadenet og vigtigste bygninger, således som det ses illustreret hos Athanasius Kircher, en af baroktidens betydeligste tænkere, $i$ hans store værk Turris Babel fra 1679, et værk, som fik afgørende betydning for opfattelsen af Babylon i de efterfølgende århundreder.

Det, der imidlertid er interessant for os i dag, er ikke i første række, hvor meget man tidligere vidste om oldtiden, eller hvor korrekt det var, men hvilken betydning denne viden havde. Hvordan bedømte man de gamle assyrere og babylonere, hvilke aspekter af deres kultur interesserede man sig for, og hvilken indflydelse fik det på europæernes verdensbilleder?

Når man betragter den historiske tradition, som den fremlægges her i udstillingen, kan man ikke undgå at bemærke, at den stadig på mange områ- 
der præger vores bevidsthed. Enhver epoke vurderer udfra sine egne tidsbetingede forudsætninger, som er et produkt af tidligere tiders opfattelser og fordomme. Man kunne derfor stille det spørgsmål, om vi i dag er bedre i stand til at rekonstruere et autentisk billede af oldtiden, end man var for 100 , 200 eller 300 år siden. Selv om vi i dag har flere primære kilder til oldtidens kulturhistorie, er vi ikke nødvendigvis mere objektive eller mindre hildede $\mathrm{i}$ traditionen, end man tidligere var. En af de humanistiske videnskabers vigtigste opgaver er efter min mening at påvise og afdække vore opfattelsesmønstre og fordomme og finde nye synsvinkler at betragte tingene udfra, og dermed bane vejen til en bedre forståelse af vor omverden og i sidste instans af vor egen situation.

I dag synes det $\mathrm{i}$ al almindelighed at være langt fra, at viden om fortiden kan betyde noget for det moderne menneskes religion eller livsopfattelse, i stedet får studiet af oldtiden mere og mere karakter af fritidsbeskæftigelse. Museumsbesøg og turistrejser med gamle og fremmedartede kulturer som mål er blevet almindelige, og underholdningsindustrien griber begærligt enhver antydning af, hvad der er eksotisk eller okkult: film, videospil og fantasyromaner vrimler med dæmoner og magikere fra gamle kulturer, også fra Assyrien og Babylonien.

Der er der sådan set intet forkert i. Også tidligere tiders oldtidsforskere ikke mindst de, der rejste i Orienten - var eventyrere og begejstredes af det fremmedartede - også fordi det dengang var underholdende og spændende. Men det ville rigtig nok være sørgeligt, hvis den enste betydning, oldtiden har i dag, er underholdning.

Udstillingen viser, at Babylonien og Assyrien igennem historisk tid har haft en afgørende plads i europæernes historiske univers, skønt de færreste i dag er klar over dette, og skønt det gamle Mesopotamien og hvad denne kultur står for betyder meget lidt eller intet for de allerfleste. Lad mig derfor slutte med håbet om, at denne udstilling kan bidrage til at vække en mere dybtgående interesse for studiet af de gamle kulturer og en større bevidsthed om den betydning, de har for vores egen kultur. 
